Saudi Journal of Oral and Dental Research

Abbreviated Key Title: Saudi J Oral Dent Res

ISSN 2518-1300 (Print) |ISSN 2518-1297 (Online)

Scholars Middle East Publishers, Dubai, United Arab Emirates

Journal homepage: https://saudijournals.com/sjodr

Review Article

\title{
Periodontal Growth Factors in Wound Healing
}

Dr. Kousain Sehar ${ }^{1}$, Dr. Navneet Kour ${ }^{1}$, Dr. Nadia Irshad ${ }^{2 *}$, Dr. Mir Tabish Syeed ${ }^{2}$, Dr. Manju Verma ${ }^{2}$

${ }^{1}$ MDS, Department of Periodontology and Implantology, BRS Dental College and Hospital Sultanpur Panchkula, Billa to Asrewali, Panchkula, Haryana 134109, India

${ }^{2}$ MDS, Department of Paedontics and Preventive Dentistry, BRS Dental College and Hospital Sultanpur Panchkula, Billa to Asrewali, Panchkula, Haryana 134109 , India

DOI: $10.36348 /$ sjodr.2020.v05i07.006

| Received: 01.07.2020 | Accepted: 09.07.2020 | Published: 12.07.2020

*Corresponding author: Dr. Nadia Irshad

\section{Abstract}

Wound healing is a process of tissue repair which involves tissue response to injury. It is a series of biological events begins as hemostasis but then involves an inflammatory responses, formation of connective tissue, covering the wound with epithelium as well as remodeling of the wound.

Keywords: Connective tissue, inflammatory, repair, remodeling, wound healing.

Copyright @ 2020: This is an open-access article distributed under the terms of the Creative Commons Attribution license which permits unrestricted use, distribution, and reproduction in any medium for non-commercial use (NonCommercial, or CC-BY-NC) provided the original author and source are credited.

\section{INTRODUCTION}

In general when an injury occur a well ocshertrated cell-cell \& cell extracellular matrix interaction is initiated which begins the healing process.

Wound healing, therefore, is divided into three phases: inflammation, fibroplasia, and maturation. Each of these phases is controlled and regulated by biologically active substances called growth factors [1]. Growth factors are biologically active polypeptides affecting the proliferation, chemotaxis and differentiation of cells from epithelium, bone and connective tissue. They express the actions by binding to specific cell-surface receptors which are present on various target cells such as osteoblasts, cementoblasts and periodontal ligament fibroblasts. Regeneration of periodontal structures lost during periodontal diseases constitutes a complex biological process regulated among others by interactions between cells and growth factors [2].

Neovascularization is required for providing nutrients to the wound and help maintain the granulation tissue bed. Angiogenesis has been attributed to various molecules, including fibroblast growth factor (FGF), VEGF, TGF-beta, angiogenin, the angiotropina, the angiopoietin-1 to tumor necrosis factor alpha (TNFalpha) and thrombospondin [3]. Activated platelets at the wound margins releases growth factors involving platelet-derived growth factor (PDGF), transforming growth factor (TGF)-alpha and epidermal growth factor etc. Cells adjacent to the injured site also are induced to release growth factors such as insulin-like growth factor-I, PDGF, TGF-alpha and TGF-alpha within a few hours after injury. 


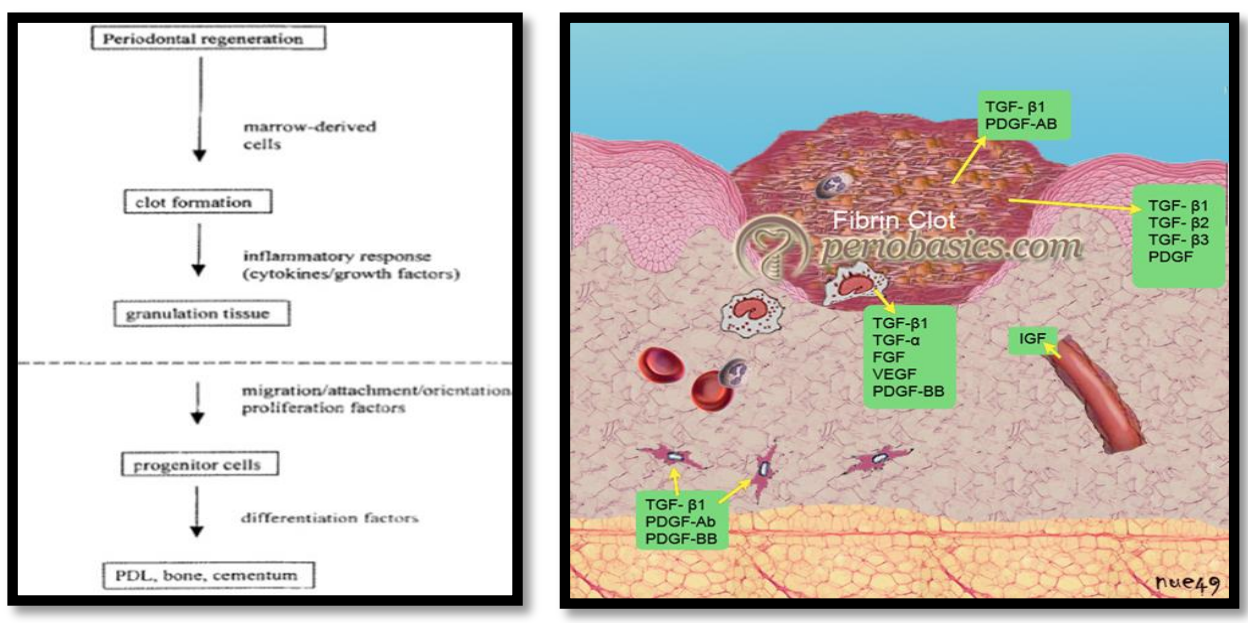

Fig-1: Mechanism Showing Periodontal Regeneration

When it comes to periodontal regeneration, the coronal establishment of the periodontal ligament (PDL) is required with corresponding cementum and the supporting alveolar bone. Thus, agents which promotes periodontal ligament fibroblast (PLF) proliferation, migration as well as collagen biosynthesis appears as mediators for enhancing the new PDL formation. When combinations of different factors are used, greater repair is achieved than when individual factors are applied.

Table-1: Showing Growth Factors and Their ROLR in Periodontal Wound Healing

\begin{tabular}{|c|c|c|c|}
\hline $\begin{array}{l}\text { WOUND } \\
\text { HEALING } \\
\text { PHASES }\end{array}$ & $\begin{array}{c}\text { GROWTH } \\
\text { FACTOR }\end{array}$ & SECRETED FROM & FUNCTIONS \\
\hline $\begin{array}{l}\text { INFLAMMATORY } \\
\text { PHASE }\end{array}$ & $\begin{array}{l}\text { PDGF } \\
\text { VEGF } \\
\text { TGF- } \alpha\end{array}$ & $\begin{array}{l}\text { Platelets } \\
\text { Platelets } \\
\text { Leucocytes } \\
\text { Fibroblasts } \\
\text { Platelets } \\
\text { Leucocytes } \\
\text { Fibroblasts }\end{array}$ & $\begin{array}{l}\text { Increase chemotaxis of neutrophil and macrophage. } \\
\text { Increase vascular permeability } \\
\text { chemotaxis of neutrophil and monocytes. } \\
\text { Autocrine expression, generation of addition cytokines (TGF-alpha, IL-1 } \\
\text { beta, PDGF, chemokines) }\end{array}$ \\
\hline $\begin{array}{l}\text { PROLIFERATIVE } \\
\text { PHASE }\end{array}$ & $\begin{array}{l}\text { PGF } \\
\text { KGF(FGF-7) } \\
\text { FGF-2 } \\
\text { PDGF } \\
\text { VEGF } \\
\text { TGF- } \beta \\
\text { BMP-2-4 } \\
\text { BMP-7 } \\
\text { FGF-2 }\end{array}$ & $\begin{array}{l}\text { Platelets } \\
\text { Mesenchymal cells } \\
\text { Macrophages } \\
\text { Keratinocytes } \\
\text { Fibroblast } \\
\text { Macrophages } \\
\text { Endothelial cells } \\
\text { Macrophages } \\
\text { Endothelial cells } \\
\text { Macrophages } \\
\text { Macrophages leucocytes } \\
\text { fibroblasts } \\
\text { Osteoblasts } \\
\text { Osteoblast } \\
\text { Macrophages } \\
\text { Endothelial cells }\end{array}$ & $\begin{array}{l}\text { Stimulate epithelial proliferation \& migration } \\
\text { Stimulate epithelial proliferation \& migration } \\
\text { Stimulate fibroblast proliferation \&ECM synthesis, increases } \\
\text { Chemotaxis \& proliferation \& differentiation of endothelial cells. } \\
\text { Stimulate fibroblast\& proliferation \& ECM synthesis increases chemotaxis } \\
\text { proliferation \& differentiation of endothelial cells. } \\
\text { Increases Chemotaxis of endothelial progenitor cells\& stimulates } \\
\text { endothelial cells proliferation. } \\
\text { Stimulates epithelial proliferation and migration, stimulatesfibroblast } \\
\text { proliferation \& ECM, inhibits proteases enhances inhibitors production. } \\
\text { Stimulates mesenchymal progenitor cells migration. } \\
\text { Stimulates osteoblast \& chondroblast differentiation. } \\
\text { Stimulates mesenchymal progenitor cells migration. }\end{array}$ \\
\hline $\begin{array}{l}\text { BONE } \\
\text { REMODELLING \& } \\
\text { MATRIX } \\
\text { SYNTHESIS }\end{array}$ & $\begin{array}{l}\text { IGF-2 } \\
\text { PDGF } \\
\text { TGF- } \beta \\
\text { VEGF }\end{array}$ & $\begin{array}{l}\text { Macrophages } \\
\text { Fibroblast } \\
\text { Macrophages } \\
\text { Fibroblast } \\
\text { Osteoblast } \\
\text { Macrophages }\end{array}$ & $\begin{array}{l}\text { Stimulates osteoblast proliferation \& bone matrix synthesis. } \\
\text { Stimulates differentiation of fibroblast into myofibroblast, stimulates } \\
\text { proliferation of mesenchymal progenitor cells. } \\
\text { Induces endothelial cell \& fibroblast apoptosis, induces differentiation of } \\
\text { fibroblast into myofibroblast, and stimulates chemo taxis \& survival of } \\
\text { osteoblast. } \\
\text { Chemotaxis of mesenchymal stem cells. Antiapoptotic effect on the bone } \\
\text { forming cells. Angiogenesis promotion. }\end{array}$ \\
\hline
\end{tabular}




\section{Source of periodontal regeneration}

Periodontal regeneration is dependent on recruitment of mesenchymal stem or stromal cells (MSCs) to the site of the intrabony defects have been identified in the perivascular space or other special niches in adult tissue, including the PDL \& stromal compartment of the bone marrow. MSCs are multipotent cells capable of differentiating into the osteoblast \& other special cell types.

The PDL contain stem cells population is also capable of differentiating into cementoblast, both PDL \& alveolar bone marrow are critical sources of progenitor cells for periodontal regeneration.Some clinicians perform intra marrow penetration or decortications to promote bleeding \& cellular movement from bone marrow into the defect site.

Therapeutic application of growth factor arises to restores damaged periodontal tissue by regeneration through biomimetic process or by imitating the process that occur during embryonic \& post natal development [17].

- Systemic circulation

- Local source

- Salivary glands

Table-2: Showing Different Growth Factors

\begin{tabular}{|l|l|l|}
\hline S. No & Growth Factor & Researcher/ s \\
\hline 1. & Bone morphogenic protein & $\begin{array}{l}\text { Urist } \text { et al., Wozney JM } \text { et al., } \\
\text { Reddi M } \text { et al., }\end{array}$ \\
\hline 2. & Platelet Derived Growth Factor & Lynch SE et al., \\
\hline 3. & Fibroblast Growth Factor & Shinya Murakami et al., \\
\hline 4. & Transforming growth factor beta & Shigeno K et al., Teare JA and Ripamonti U et al., \\
\hline 5. & Insulin like growth factor 1,2 & Lynch SE et al., and Rutherford RB et al., \\
\hline 6. & Enamel Matrix proteins & Hammastrom et al., Heijl et al., Sculean et al., Rasperini et al., \\
\hline 7. & Teriparatide & Bashutski JD et al., \\
\hline 8. & Growth \& Differentiation factor 5 & Koch FP et al., Wikesjo et al., \\
\hline
\end{tabular}

\section{Platelet-Rich Plasma/Fibrin in Periodontal Therapy}

PDGF is also one important factor in plateletrich plasma (PRP) that has been advocated for periodontal regeneration. PRP is prepared in the office from the patient's own blood, typically by a two-step centrifugation, and the platelets are then activated with thrombin. PRP contains several growth factors released mainly from activated platelets, including PDGF-AB (100-300 ng/mL), significantly less PDGF-BB, high levels of Transforming Growth Factor-b (TGF-b; 100-
$500 \mathrm{ng} / \mathrm{mL}$ ) and also some IGF-1 and VEGF [18, 19]. However, the concentration of these factors can vary considerably in different PRP preparations, possibly due to differences in plasma collection and processing, the efficiency of platelet activation, and variations in plasma composition between different donors. Nevertheless, the concentration of total PDGF in the PRP is less than a thousand-fold compared to GEM $21 \mathrm{~S} \circledast[20]$.

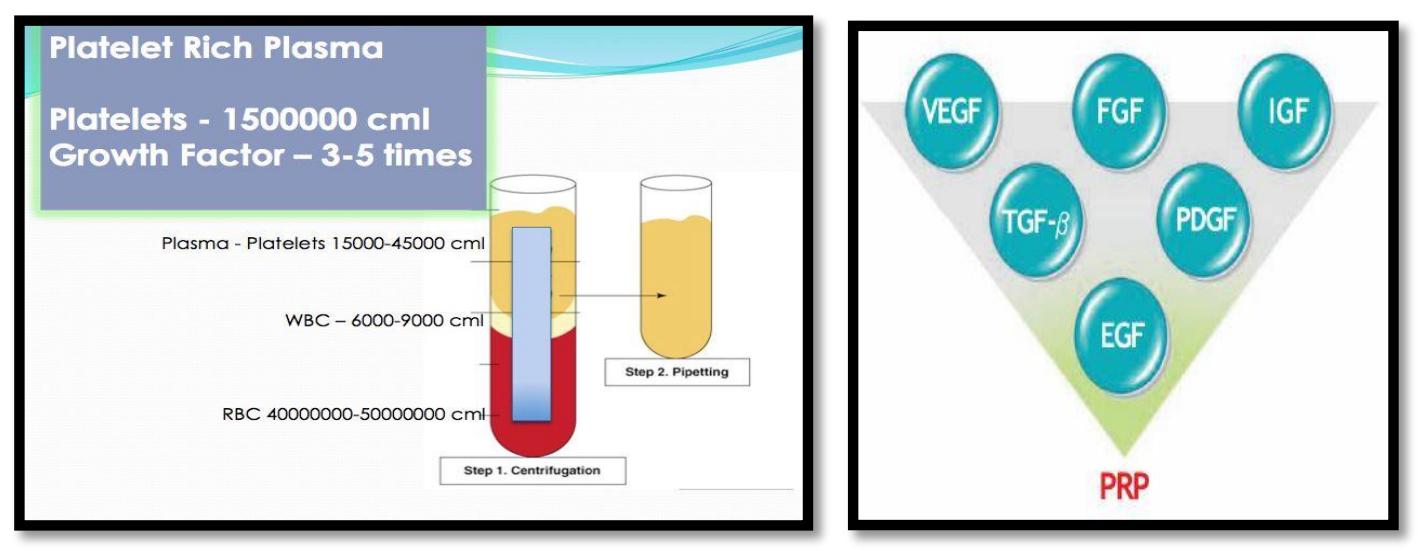

Fig-2: Showing Platelet Rich Plasma

A large number of case studies and clinical trials have been performed using PRP in periodontal defects [4, 5]. For example, in two randomized controlled clinical trials with a limited number of patients and using a split-mouth approach, different outcomes were reported. In one study, PRP mixed with
b-TCP did not seem to improve the clinical outcome in intrabony defects in periodontitis patients [21]. In the other study, PRP was applied directly to the periodontal defect and then bovine bone xenograft mixed with $\mathrm{PRP}^{6,7}$ was added to fill the defect while the control sites received the xenograft only. 
Table-3: Various Growth Factors in Periodontal Wound Healing

\begin{tabular}{|c|c|c|c|}
\hline S. No & Platelet concentrate & Author /s & Advantages \\
\hline 1. & $\begin{array}{l}\text { Platelet Rich plasma (PRP)- } 2 \text { spins } \\
\text { Separation and concentration spins } \\
\text { Addition of agent for platelet } \\
\text { activation } \\
\text { P-PRP and L-PRP }\end{array}$ & $\begin{array}{l}\text { Marx et al., } \\
\text { Anitua } \text { et al., } \\
\text { Landesberg } \text { et al., } \\
\text { Choi } \text { et al., }\end{array}$ & Gel like structure with activated platelets \\
\hline 2. & $\begin{array}{l}\text { Platelet Rich Fibrin } \\
\text { P-PRF }\end{array}$ & Choukron et al., & $\begin{array}{l}\text { Fibrin meshwork with entrapped platelets- } \\
\text { glass is activator }\end{array}$ \\
\hline 3. & Leukocytes rich platelet rich fibrin & Dohan et al., & 15 Times $>$ VEGF and $2>$ TGF beta \\
\hline 4. & $\begin{array}{l}\text { Titanium prepared PRF (T-PRF) } \\
\text { Titanium coated tube } \\
2800 \mathrm{rpm} \text { for } 12 \mathrm{mts}\end{array}$ & Tunali et al., & $\begin{array}{l}\text { Titanium is more effective activator than } \\
\text { glass }\end{array}$ \\
\hline 5 & $\begin{array}{l}\text { A-PRF- Has anticoagulant } \\
1500 \mathrm{rpm}, 14 \mathrm{mts}\end{array}$ & Ghanaati S et al., & $\begin{array}{l}\text { More amount of granulocytes/ monocytes, } \\
50 \% \text { more BMP. }\end{array}$ \\
\hline
\end{tabular}

Significant clinical improvement in periodontal parameters was reported in this study. Studies using PRP have used inconsistent methods for collection and activation of PRP, different carriers for mixing it, and variable application methods, which may explain the heterogeneity of the clinical outcomes. In many studies, the concentrations of growth factors in the final product were also not reported. Nor is it known how quickly the growth factors are released from various combinations of PRP and bone grafts [7].

Table-4: Difference between First Generatiom PRP and Second Generation PRP

\begin{tabular}{|l|l|}
\hline First generation- Platelet concentrate- PRP & Second generation- Platelet rich fibrin \\
\hline Use of bovine thrombin and calcium chloride & Not used \\
\hline $\begin{array}{l}\text { Sudden firbin polymerization following addition } \\
\text { of the thrombin and calcium chloride }\end{array}$ & $\begin{array}{l}\text { Slow natural polymerization when in contact with the glass wall } \\
\text { of the tube at a physiologic concentration of thrombin }\end{array}$ \\
\hline $\begin{array}{l}\text { 3-D constiution: Thick fibrin network- Tetra } \\
\text { molecular framework- rigid. }\end{array}$ & $\begin{array}{l}\text { 3-D constiution: Thinner and more flexible fibrin network- Tri- } \\
\text { molecular framework. } \\
\text { Not favorable for cell migration/ cytokine } \\
\text { enmeshment }\end{array}$ \\
\hline $\begin{array}{l}\text { Risk of inducing abnormal clotting in the host- } \\
\text { thrombin is added }\end{array}$ & No such risk \\
\hline Antigenic response to bovine thrombin & No antigenic response \\
\hline
\end{tabular}

PRP has also been used for the treatment of gingival recessions, class II furcation defects, and sinus graft procedures. However, it does not seem to improve the clinical outcome in these conditions. In summary, although promising results with PRP have been reported, more studies need to be performed to optimize PRP collection, preparation, and application techniques before it can be applied more widely to clinical practice in periodontics [22].

Among platelet concentrates, platelet-rich fibrin (PRF) belongs to a group of second-generation blood autologous preparations that was originally described by Choukroun et al., [8, 9]. Platelet-rich fibrin is obtained by gentle centrifugation of peripheral blood and is characterized as being leukocyte and platelet rich and fibrin dense [10], besides not requiring the addition of any anticlotting agent. Dohan Ehrenfest et al., [11] showed that approximately $97 \%$ of platelets and $50 \%$ of leukocytes of the original blood volume were concentrated and three dimensionally distributed in the PRF clot, which is one of the three layers resulting from the centrifugation process.

After its preparation and collection, PRF can be used directly as a filler agent or compressed into a membrane. In either of those applications, PRF is believed to release polypeptide growth factors, such as transforming growth factor-b1, platelet- derived growth factor, vascular endothelial growth factor and matrix glycoproteins (such as thrombospondin- 1), into the surgical wound in a sustained fashion for at least 7 days, as shown in vitro. 


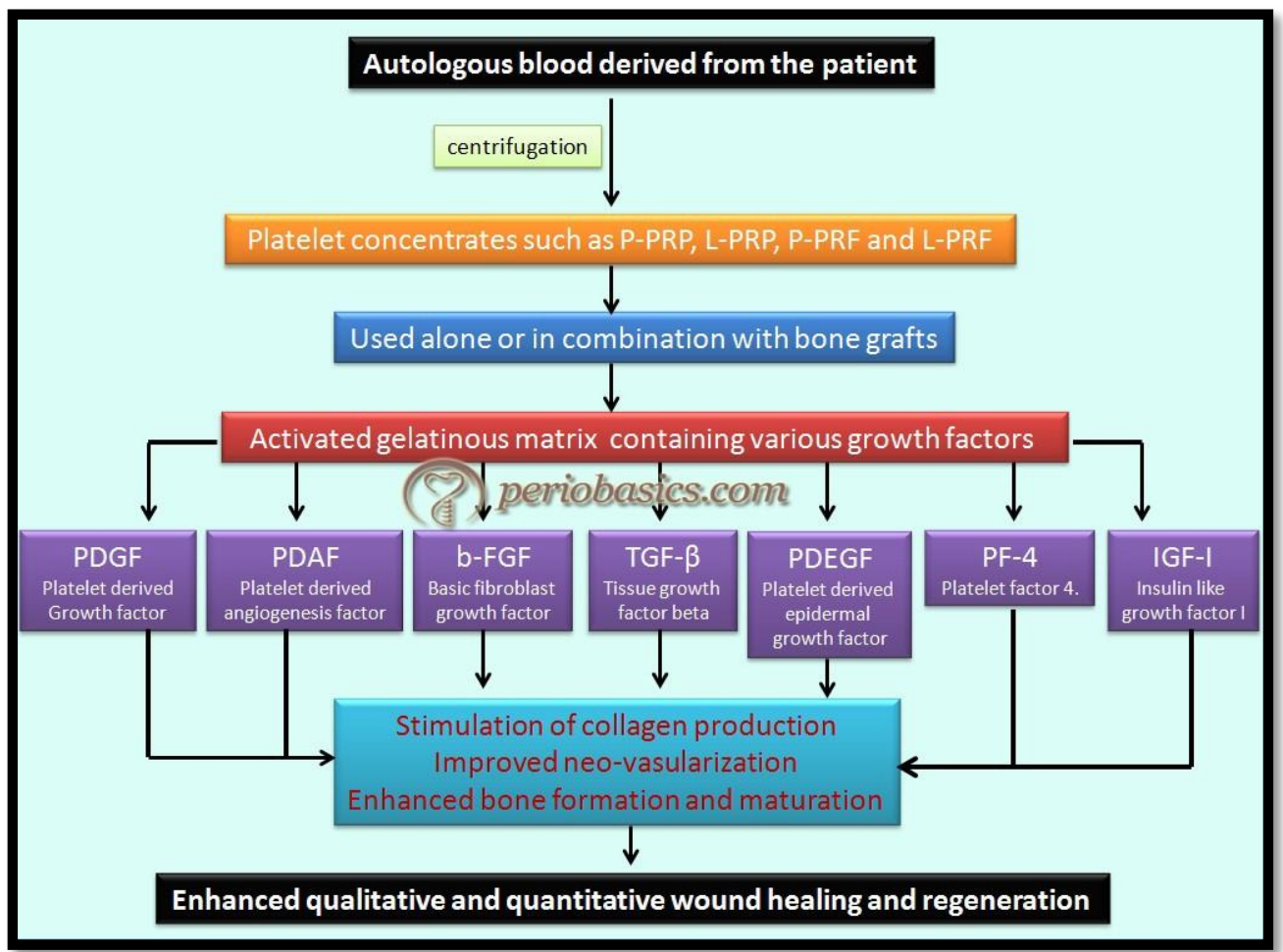

Fig-3: Showing Enhanced Wound Healing and Regeneration

Table-5: Bone Morphogenic Proteins

\begin{tabular}{|l|l|l|l|l|}
\hline Agent & BMP-2 & BMP-7 & GDF-5 & Teriparatide \\
\hline Origin & $\begin{array}{l}\text { Recombinant DNA } \\
\text { technology- mammalian } \\
\text { cells }\end{array}$ & $\begin{array}{l}\text { Recombinant DNA } \\
\text { technology- } \\
\text { Mammalian cells }\end{array}$ & $\begin{array}{l}\text { Recombinant DNA } \\
\text { technology- } \\
\text { microbial cells } \\
\text { In vitro }\end{array}$ & Recombinant DNA \\
\hline Composition & $\begin{array}{l}\text { Bone morphogenetic } \\
\text { protein-2 }\end{array}$ & $\begin{array}{l}\text { Bone morphogenetic } \\
\text { protein-7 }\end{array}$ & $\begin{array}{l}\text { Growth and } \\
\text { differentiation factor } \\
-5\end{array}$ & $\begin{array}{l}\text { Parathyroid } \\
\text { hormone- first 34 } \\
\text { amino acids }\end{array}$ \\
\hline MOA & $\begin{array}{l}\text { Increased proliferation, } \\
\text { mineralization, alkaline } \\
\text { phosphatase, osteocalcin }\end{array}$ & $\begin{array}{l}\text { Increased proliferation, } \\
\text { mineralization, alkaline } \\
\text { phosphatase, osteocalcin }\end{array}$ & $\begin{array}{l}\text { Increased } \\
\text { differentiation and } \\
\text { matrix production by by } \\
\text { cells }\end{array}$ & $\begin{array}{l}\text { Modify proliferation } \\
\text { of mineralized } \\
\text { markers }\end{array}$ \\
\hline $\begin{array}{l}\text { FDA } \\
\text { approval }\end{array}$ & $\begin{array}{l}\text { Sinus augmentation } \\
\text { Socket preservation }\end{array}$ & $\begin{array}{l}\text { Sinus augmentation } \\
\text { Socket preservation }\end{array}$ & $\begin{array}{l}\text { Sinus augmentation } \\
\text { Socket preservation }\end{array}$ & $\begin{array}{l}\text { Osteoporosis } \\
\text { Being tried out in } \\
\text { Implants for } \\
\text { osseointegration }\end{array}$ \\
\hline $\begin{array}{l}\text { Commercial } \\
\text { names }\end{array}$ & Infuse & Osigraft & Scil technology & Forteo \\
\hline
\end{tabular}

The operational reconstitution \& the implantation of the BMP with the collagenous matrix as carrier resulted in induced cemtogenesis.

There are a few reports on the use of PRF in the regenerative treatment of periodontal defects in humans, but none of those investigated its effectiveness in treating interproximal intrabony defects $[12,13]$.

Important function for an osteogenic delivery system in the initiation of optimal osteoinductivity with relatively low doses of recombinant BMPs.
Hakki \& co-workers studied the effects of BMP on cementoblast showing that it regulates the expression of mineralised tissue-associated genes.

\section{Growth and Differentiation Factor-5 in Periodontal Regeneration}

Growth and Differentiation Factor-5 (GDF-5) is a member of the Bone Morphogenic Proteins (BMPs) and related in amino acid sequence and function to GDF-6 (BMP-13) and -7 (BMP-12). 
GDF-5 binds to type I BMP receptor on the cell surface and then complexes with the type II receptor to induce signaling via the Smad signaling pathway - Bragdon 2011. Mice with a natural mutation in the GDF-5 gene (bp mice) show abnormalities in various tissues including cartilage, tendon, skin, and bone. Interestingly, ectopic administration of GDF-5 results in tendon and ligament formation, suggesting that it can induce precursor/stem cell differentiation toward mesenchymal cells which can form tendon/ ligament [23].

In addition to ligament repair, GDF-5 has been shown to stimulate cartilage and bone healing in a variety of animal models. In craniofacial applications, GDF-5 was demonstrated to enhance bone formation, defect fill, and osteointegration of titanium implants. The osseous fill was found to be similar to autologous bone/b-TCF mixture.

\section{Role of Bioactive Collagen-Derived Peptides in Periodontal Regeneration}

A synthetic peptide derived from the type I collagen cell binding region has been developed into a commercial product recommended for intrabony periodontal osseous defects, ridge augmentations, socket preservation, and sinus elevation procedures (PepGen P-15®; Dentsply). This 15-amino-acid peptide (GTPGPQGIAGQRGVV) corresponding to Amino acids 766-780 in type I collagen alpha-1 chain) embedded in bovine inorganic xenograft (called anorganic bovine-derived bone material, ABM) has been shown to increase dermal and human periodontal ligament fibroblast adhesion and osteogenic differentiation in vitro. This peptide also inhibits fibroblast adhesion to collagen. Regardless, in vitro studies have demonstrated that P-15 may also promote cell survival and inhibit apoptosis.

\section{PepGen P-15}

Tissue-engineered bone replacement graft material. Mimics the inorganic and organic components of autogenous bone. Includes the specially designed P15 peptide, a synthetic biomimetic of the 15 amino acid sequence of Type-I collagen, which is uniquely involved in the binding of cells, particularly fibroblasts and osteoblasts [24].

Periodontal tissue regeneration with PRP incorporated gelatin hydrogel sponges [25].

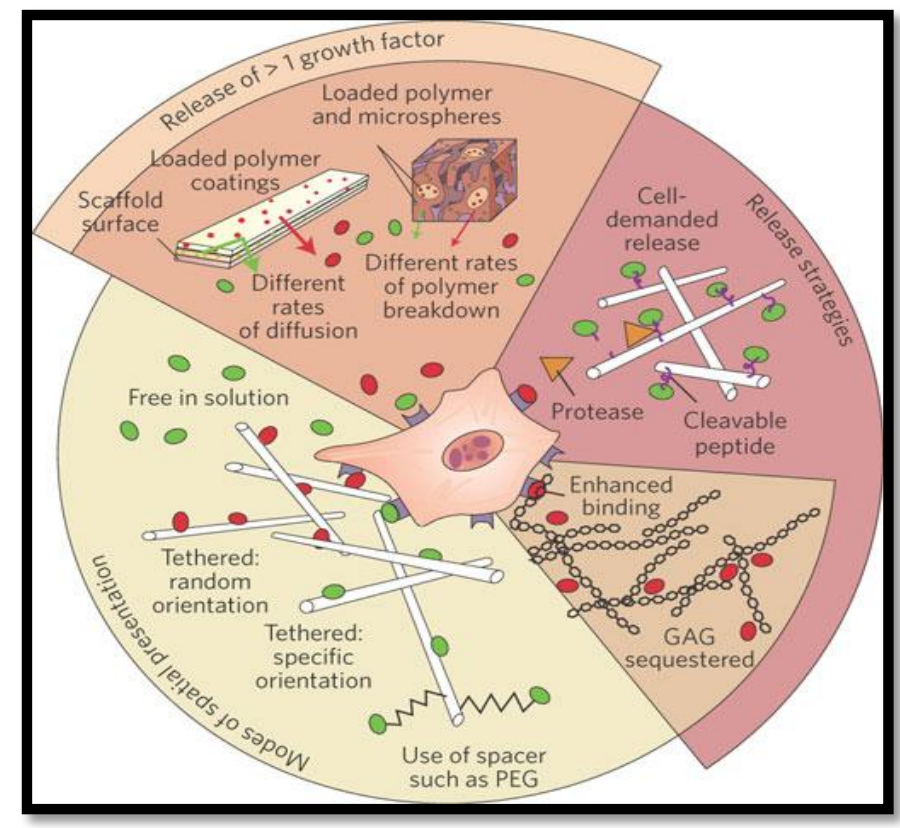

Fig-4: Peptides Showing Periodontal Regeneration

Enamel Matrix Proteins in Periodontal Regeneration and Wound Healing

Enamel matrix proteins (EMPs) have been used for over a decade in clinical periodontics for tissue regeneration, with multiple reports supporting significant gain of attachment [14].
Amelogenins comprise about $90 \%$ of EMPs but other enamel proteins and proteolytic enzymes, protease inhibitors, and TGF-b1 may also be present. Amelogenins are well conserved in evolution, suggesting that they are crucial for the biomineralization of enamel [15]. 


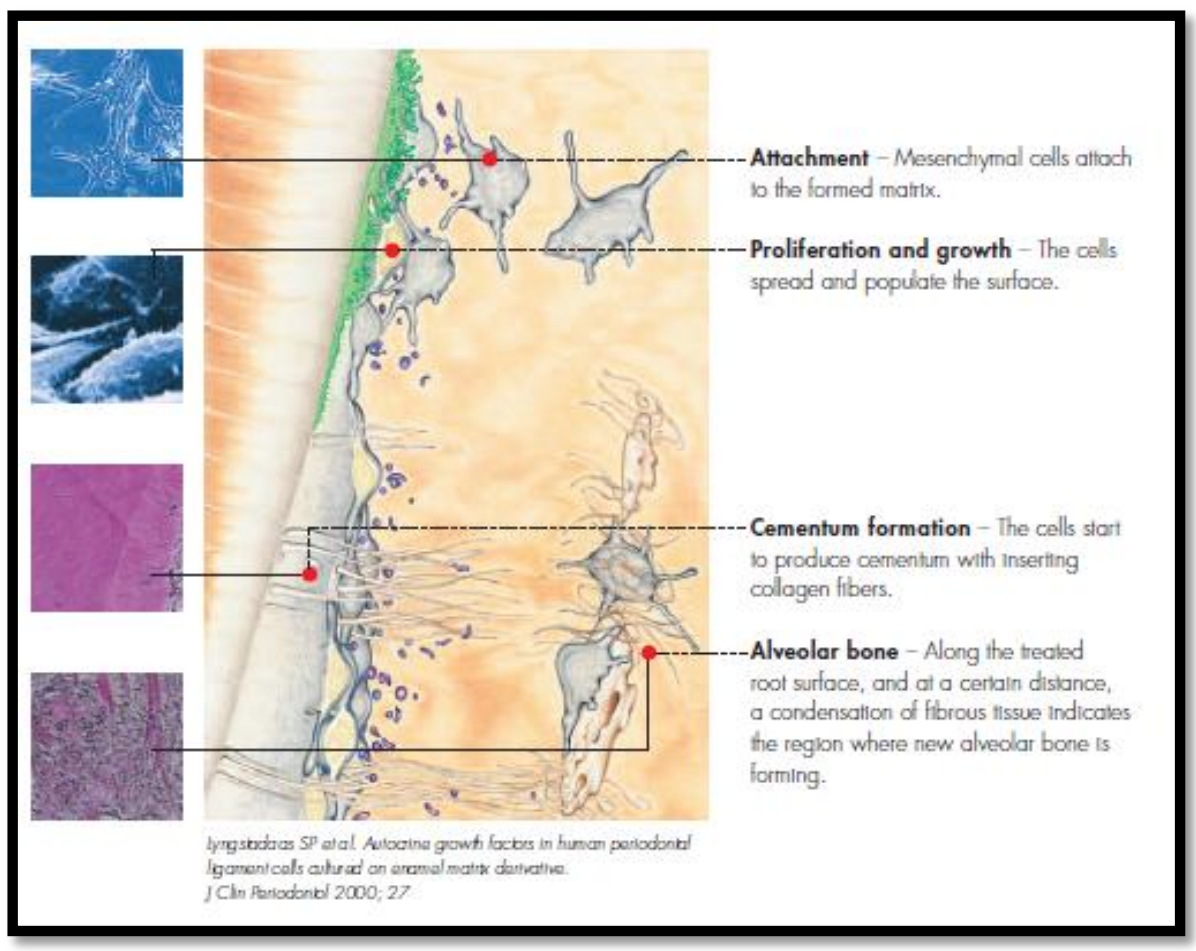

Fig-5: EMP in Periodontal Regeneration and Wound Healing

Amelogenins are rich in hydrophobic amino acids, making them insoluble in water and able to selfassemble into supramolecular nanospheres. Therefore, for clinical applications, EMPs are solubilized into gel form using propylene glycolalginate (PGA) as a carrier vehicle. When applied to a clinical lesion, EMPs presumably precipitate onto the root surface where they regulate periodontal regeneration. This is supported by findings from human histological studies showing that EMPs can promote the formation of cementum, PDL, and bone $[15,16]$.

EMPs function to support periodontal regeneration are still only partially understood EMPs seem to enhance the adhesion, proliferation, and matrix production of fibroblasts but not epithelial cells The attachment of human PDLFs to EMP is possibly mediated by bone sialoprotein and can be inhibited by RGD-containing peptides and with an anti-avb3 integrin antibody.

EMP can also bind to different extracellular matrix proteins utilized by keratinocytes and the binding of EMPs to fibronectin or collagen may in fact reduce epithelial cell binding to these molecules. Thus, EMPs appear to have the ability to reduce keratinocyte adhesion to extracellular matrix and inhibit their migration. This mechanism may play a significant role in periodontal regeneration, allowing time for periodontal ligament fibroblasts (PDLFs) to gain access to the root surface prior to epithelial cells.

In periodontal lesions, EMPs must interact with the other matrix proteins such as fibronectin and type I collagen, which are major cell adhesion proteins for fibroblasts and also play a critical role in collagen fibrillogenesis. Both fibronectin and type I collagen seem to bind to EMP, while there was no binding of type IV collagen or laminin-1.

Once the osteogenic cells have been induced by other factors, EMPs are able to enhance their differentiation. This property may be beneficial for periodontal regeneration as it may prevent ankylosis of the EMP treated roots. An increased incidence of ankylosis has been described in periodontal sites that were treated with BMP-2 which stimulates osteoblasts differentiation.

In summary, EMPs appear to have a positive effect on clinical periodontal regeneration, although results are variable. This heterogeneity in treatment outcomes may depend on EMP dose or aggregation of EMPs in the tissues. Although the exact mechanisms of actions of EMPs are still unknown, they seem to stimulate fibroblast proliferation, growth factor expression, angiogenesis, and enhance osteogenic differentiation of committed cells. Furthermore, EMPs seem to reduce inflammation.

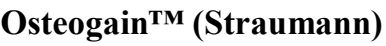

Osteogain significantly upregulated the expression of 20 of the 100 genes examined which included bone morphogenetic protein 2 (BMP2), TGF $\beta 1$, fibroblast growth factor (FGF), epidermal growth factor (EGF) and platelet-derived growth factor (PDGF) and some associated receptors [26]. 


\section{CONCLUSION}

Growth factors are natural cell products that are released or activated when cell division is needed which occurs during such events as wound healing and tissue regeneration. Activated platelets at the wound margins release several growth factors such as plateletderived growth factor (PDGF), transforming growth factor (TGF)- $\alpha$, epidermal growth factor etc. Cells adjacent to the injured site also are induced to release growth factors such as insulin- like growth factor- I, PDGF, TGF- $\alpha$ and TGF- $\alpha$ within a few hours after injury. In periodontal regeneration, the coronal reestablishment of the periodontal ligament (PDL) is required with corresponding cementum and supporting alveolar bone. Thus, agents which promote periodontal ligament fibroblast (PLF) proliferation and migration as well as collagen biosynthesis would appear to be mediators for enhancing new PDL formation

\section{REFERENCES}

1. Steed, D. L. (1997). The role of growth factors in wound healing. Surgical Clinics of North America, 77(3), 575-586.

2. Dereka, X. E., Markopoulou, C. E., \& Vrotsos, I. A. (2006). Role of growth factors on periodontal repair. Growth Factors, 24(4), 260-267.

3. Hoeben, A. N. N., Landuyt, B., Highley, M. S., Wildiers, H., Van Oosterom, A. T., \& De Bruijn, E. A. (2004). Vascular endothelial growth factor and angiogenesis. Pharmacological reviews, 56(4), 549-580.

4. Lekovic, V., Camargo, P. M., Weinlaender, M., Vasilic, N., \& Kenney, E. B. (2002). Comparison of platelet- rich plasma, bovine porous bone mineral, and guided tissue regeneration versus platelet- rich plasma and bovine porous bone mineral in the treatment of intrabony defects: A reentry study. Journal of periodontology, 73(2), 198-205.

5. Camargo, P. M., Lekovic, V., Weinlaender, M., Vasilic, N., Madzarevic, M., \& Kenney, E. B. (2002). Platelet- rich plasma and bovine porous bone mineral combined with guided tissue regeneration in the treatment of intrabony defects in humans. Journal of Periodontal Research, 37(4), 300-306.

6. Lekovic, V., Camargo, P. M., Weinlaender, M., Vasilic, N., Aleksic, Z., \& Kenney, E. B. (2003). Effectiveness of a combination of platelet- rich plasma, bovine porous bone mineral and guided tissue regeneration in the treatment of mandibular grade II molar furcations in humans. Journal of clinical Periodontology, 30(8), 746-751.

7. Camargo, P. M., Lekovic, V., Weinlaender, M., Divnic- Resnik, T., Pavlovic, M., \& Kenney, E. B. (2009). A surgical reentry study on the influence of platelet- rich plasma in enhancing the regenerative effects of bovine porous bone mineral and guided tissue regeneration in the treatment of intrabony defects in humans. Journal of periodontology, 80(6), 915-923.

8. Choukroun, J., Adda, F., Schoeffer, C., \& Vervelle, A. (2000). PRF: an opportunity in perioimplantology. Implantodontie, 42, 55-62.

9. Ehrenfest, D. M. D., Rasmusson, L., \& Albrektsson, T. (2009). Classification of platelet concentrates: from pure platelet-rich plasma $(\mathrm{P}$ $\mathrm{PRP}$ ) to leucocyte-and platelet-rich fibrin (LPRF). Trends in biotechnology, 27(3), 158-167.

10. Dohan, D. M., Choukroun, J., Diss, A., Dohan, S. L., Dohan, A. J., Mouhyi, J., \& Gogly, B. (2006). Platelet-rich fibrin (PRF): a second-generation platelet concentrate. Part II: platelet-related biologic features. Oral Surgery, Oral Medicine, Oral Pathology, Oral Radiology, and Endodontology, 101(3), e45-e50.

11. Dohan Ehrenfest, D. M., Del Corso, M., Diss, A., Mouhyi, J., \& Charrier, J. B. (2010). Threedimensional architecture and cell composition of a Choukroun's platelet- rich fibrin clot and membrane. Journal of periodontology, 81(4), 546555.

12. Jankovic, S., Zoran, A., Iva, M., \& Bozidar, D. (2010). The coronally advanced flap in combination with platelet-rich fibrin (PRF) and enamel matrix derivative in the treatment of gingival recession: a comparative study. Eur $J$ Esthet Dent, 5(3):260-273.

13. Aroca, S., Keglevich, T., Barbieri, B., Gera, I., \& Etienne, D. (2009). Clinical evaluation of a modified coronally advanced flap alone or in combination with a platelet- rich fibrin membrane for the treatment of adjacent multiple gingival recessions: A 6- month study. Journal of periodontology, 80(2), 244-252.

14. Nagano, T. (2006). Emdogain: mixture of amelogenin, enamelin, tuftelin ameloblastin, TGF beta: porcine tooth bud.

15. Černý, R., Slaby, I., Hammarström, L., \& Wurtz, T. (1996). A novel gene expressed in rat ameloblasts codes for proteins with cell binding domains. Journal of Bone and Mineral Research, 11(7), 883-891.

16. Boabaid, F., Gibson, C. W., Kuehl, M. A., Berry, J. E., Snead, M. L., Nociti Jr, F. H., ... \& Somerman, M. J. (2004). Leucine- rich amelogenin peptide: A candidate signaling molecule during cementogenesis. Journal of periodontology, 75(8), 1126-1136.

17. Alvarez, R. H., Valero, V., \& Hortobagyi, G. N. (2010). Emerging targeted therapies for breast cancer. J Clin Oncol, 28(20), 3366-3379.

18. Eppley, B. L., Pietrzak, W. S., \& Blanton, M. (2006). Platelet-rich plasma: a review of biology and applications in plastic surgery. Plastic and reconstructive surgery, $118(6), 147 \mathrm{e}-159 \mathrm{e}$.

19. Kotsovilis, S., Markou, N., Pepelassi, E., \& Nikolidakis, D. (2010). The adjunctive use of platelet- rich plasma in the therapy of periodontal 
intraosseous defects: A systematic review. Journal of periodontal research, 45(3), 428-443.

20. Landesberg, R., Roy, M., \& Glickman, R. S. (2000). Quantification of growth factor levels using a simplified method of platelet-rich plasma gel preparation. Journal of Oral and Maxillofacial Surgery, 58(3), 297-300.

21. Harnack, K., Andersen, G., \& Somoza, V. (2009). Quantitation of alpha-linolenic acid elongation to eicosapentaenoic and docosahexaenoic acid as affected by the ratio of $\mathrm{n} 6 / \mathrm{n} 3$ fatty acids. Nutrition \& metabolism, 6(1), 8 .

22. Arora, A., Dien, B. S., Belyea, R. L., Singh, V., Tumbleson, M. E., \& Rausch, K. D. (2010). Nutrient recovery from the dry grind process using sequential micro and ultrafiltration of thin stillage. Bioresource technology, 101(11), 38593863.

23. Wolfman, N. M., Hattersley, G., Cox, K., Celeste, A. J., Nelson, R., Yamaji, N., ... \& Wozney, J. M.
(1997). Ectopic induction of tendon and ligament in rats by growth and differentiation factors 5, 6, and 7, members of the TGF-beta gene family. The Journal of clinical investigation, 100(2), 321-330.

24. Wang, J. K., Xiong, G. M., Zhu, M., Özyilmaz, B., Castro Neto, A. H., Tan, N. S., \& Choong, C. (2015). Polymer-enriched 3D graphene foams for biomedical applications. ACS applied materials \& interfaces, 7(15), 8275-8283.

25. Nakajima, D., Tabata, Y., \& Sato, S. (2015). Periodontal tissue regeneration with PRP incorporated gelatin hydrogel sponges. Biomedical Materials, 10(5), 055016.

26. Miron, R. J., Zhang, Q., Sculean, A., Buser, D., Pippenger, B. E., Dard, M., ... \& Zhang, Y. (2016). Osteoinductive potential of 4 commonly employed bone grafts. Clinical oral investigations, 20(8), 2259-2265. 